УДК 78.071.2(477)

DOI:

Оксана Бобечко, кандидат мистецтвознавства, доиент кафедри народних музичних інструментів та вокалу Дрогобицького державного педагогічного університету імені Івана Франка Наталія Шевченко, студентка магістратури Інституту музичного мистеитва Дрогобицького державного педагогічного університету імені Івана Франка

\title{
МИХАЙЛО ГОЛИНСЬКИЙ - СПІВАК СВІТОВОЇ СЛАВИ
}

У статті розглядається творча постать видатного співака Михайла Голинського, щчо став гордістю вітчизняної вокальної школи, а також окрасою багатьох оперних сиен та концертних майданчиків Свропи, Америки, Канади. Висвітлюється подвижницька творчо-виконавська діяльність мития, яка є втіленням великого культурно-мистеиького потенціалу украӥнської начії. Зазначається, щзо проживаючи за кордоном співак зберіг своє національне коріння та долучився до духовного збагачення представників украӥнської діаспори та міжнародної спільноти.

Ключові слова: Михайло Голинський; співак; творчо-виконавська діяльність; вокальне мистечтво; опера; камерно-вокальна музика.

Jim. 9.

\author{
Oksana Bobechko, Ph.D.(Art Studies), Associate Professor of the \\ Folk Musical Instruments and Vocal Department \\ Drohobych Ivan Franko State Pedagogical University \\ Nataliya Shevchenko, Master Student at the Institute of Musical Art of \\ Drohobych Ivan Franko State Pedagogical University
}

\section{MYKHAYLIO HOLYNSKIY - A WORLD FAMOUS SINGER}

The article deals with the creative personality of the outstanding singer Mykhaylo Holynskiy, who became the pride of the national vocal school, as well as a showcase example of many opera scenes and concert venues of Europe, America and Canada. The stages of his formation as a professional singer are covered. The versatile repertoire of $M$. Holynskiy and the contribution of the artist to the formation and development of state opera theaters of Odessa, Kyiv and Kharkiv are considered. The emphasis is made on the Ukrainian-language performances of the singer at the opera stages of Moscow and Tbilisi. It is also noted that the artist was an active participant in the musical and social life of Galicia. Much attention is paid in this study to the creative periods during which M. Holynskiy lived in Europe, America and Canada. There are positive responces of reviewers and music critics who note that the period the singer spent abroad has become an important page of his creative and performing career, which was aimed at popularizing Ukrainian chamber-vocal music. The article mentions the cultural and artistic association "Kozub", which was headed by the artist for a long time, as well as the book "Spohady" ("Memoirs"), in which he left the information for his followers about the smallest details of his life enriched by interesting events and artistic accomplishments. The guides of M. Holynskiy for future singers are provided. The authors note that the dedicated creativity and performance of the artist are the embodiment of the great cultural and artistic potential of the Ukrainian nation. While living abroad, the singer managed to preserve his national roots, remained a patriot of his native country and played a role in the spiritual enrichment of the representatives of Ukrainian diaspora and the international community. Receiving recognition at leading opera and chamber stages, M. Holynskiy made a significant contribution to the development of vocal performance art of his country and the world.

Keywords: Mykhaylo Holynskiy; a singer; creative-performing activity; vocal art; opera; chamber-vocal music.

П остановка проблеми. Численні досягнення, якими може пишатися сучасна українська культура у сфері вокального мистецтва пов'язані з визначними особистостями, які заклали міцні підвалини професійного вокального виконавства та забезпечили фундаментальний розвиток української вокальної школи. Особливим місцем на мапі України, де повсякчас культивувались вокальні традиції $\epsilon$ Львів, адже “розвиток вокального виконавства у Львові пов’ язаний був
3 діяльністю початково “цісарсько-королівського привілейованого” (заснованого у 1776 р.), а потім Міського театру, котрий від драматичномузичного спрямування ставав щораз більше музично-драматичним, щоби від 1872 р. стати театром опери, оперети й драми... львів'яни щонайменше від кінця XVIII ст. добре були ознайомлені з оперним виконавством" [7, 102]. Найкращим свідоцтвом плідності львівської вокальної школи фундатором якої вважається Валерій Висоцький (1831 - 1907), стала велика 
кількість високопрофесійних співаків, які були не лише гордістю вітчизняної вокальної школи, а й окрасою багатьох оперних сцен та концертних майданчиків Свропи, Америки, Канади. Серед них уславлені співаки Олександр Мишуга, Соломія Крушельницька, Модест Менцинський, Адам Дідур, Філомена Лопатинська, Свген Гушалевич, Чеслав Заремба та багато інших. Поруч з такими видатними постатями стоїть митець світової слави - Михайло Голинський (1890 - 1973), якого називають “українським Карузо”. Саме він “...довгі роки чарував слухачів красою свого голосу і майстерністю виконання оперних партій в багатьох оперних спектаклях та на концертах" $[8,93] .2020$ року виповнюється 130 років від дня народження, видатного співака, який посів почесне місце в історії української та світової музичних культур. В цьому контексті, особливо актуальним видається звернення до особистості співака, подвижницька творчо-виконавська діяльність якого є втіленням великого культурномистецького потенціалу української нації.

Мета статті полягає у висвітленні творчовиконавської діяльності М. Голинського в контексті утвердження української музичної культури за кордоном.

Огляд останніх досліджень і публікацій. Варто зауважити, що до творчої постаті М. Голинського зверталися у своїх дослідженнях Я. Михальчишин, Г. Карась, М. Жишкович. Мемуарну та епістолярну спадщину співака, у яких розкриваються певні аспекти вокального мистецтва української діаспори, обрали предметом свого зацікавлення С. Козак, Г. Тихобаєва, I. Криворучка, Д. Білавич. Також про видатного виконавця знаходимо публікації у закордонних часописах авторства М. Гайворонського, А. Рудницького, М. Сабат-Свірської. Однак, творчо-виконавська діяльність М. Голинського, що увиразнює внесок співака в утвердження української музичної культури за кордоном, потребує більш детального висвітлення у наукових дослідженнях та залишається актуальною для опрацювання.

Виклад основного матеріалу. Народився М. Голинський 2 січня 1890 року в селі Вербівці Городенківського повіту на Станіславівщині (тепер - Івано-Франківська область) в інтелігентній родині. Його батько багато займався громадською роботою, був засновником сільської читальні “Просвіта". Змалку Михайло вирізнявся серед однолітків сильним і приємним голосом. Навчаючись у гімназіях Городенки, Коломиї, Станіславова та Львова завжди співав у хорах і виконував сольні номери як бас-баритон. Ще як гімназійний учень, був учасником хору богословів Духовної семінарії у Львові, а також Львівських хорів “Боян” i “Бандурист”. В цей період майбутній співак познайомився 3 відомим педагогом Чеславом Зарембою (1881 - 1966), який став його педагогом, та приватно впродовж 1913,1919 - 1920, 1924 - 1925 років навчав його вокальної майстерності. Педагог зумів розвинути його голос у верхньому регістрі, а відтак учень почав співати як драматичний тенор. Один 3 перших успішних виступів М. Голинського відбувся 1913 року, коли він блискуче виконав складну арію Каніо з опери “Паяци” Р. Леонкавалло, взявши участь у звітному концерті учнів школи професора Заремби. "Мій виступ був сенсаційним, мене змусила публіка відспівати арію Каніо “Смійся, паяц" три рази... По виступі прийшли гратулювати мені..., а Зарембі гратулювали, що щасливо переобразив мене з бас-баритона на героїчного тенора" [2, 49] - писав митець у своїх “Спогадах".

Під час Першої світової війни М. Голинський воював в рядах австрійської армії, однак, був поранений та переведений до Львова у канцелярію Лікарської комісії (1917). Після розпаду Австро-Угорської імперії перебував (1918) в лавах Української Галицької Армії, працював особистим секретарем отамана Бубели у секретаріатах військових справ Львова, Тернополя, Станіславова, а згодом - Вінниці та Кам'янця-Подільського. Після поразки українських визвольних змагань, які тривали впродовж 1917 - 1921 років, повертається до Львова. Вже згодом митець переїхав до Варшави, де поновив вокальні студії у Ч. Заремби. Дослухавшись до порад педагога він продовжив навчання в Італії. Протягом 1920 - 1925 років співак вдосконалював вокальну майстерність у відомого міланського педагога Едуардо Гарбіно (Гарбіна). Перебуваючи в Італії, концертував у Мілані, а також гастролював у Цюріху, Празі та Відні.

Закінчивши навчання, 1925 року М. Голинський повернувся до Львова, де за сприяння Ч. Заремби 3 великим успіхом дебютував в опері “Паяци" Р. Леонкавалло. Згадуючи про цей виступ співачка М. Сабат-Свірська відзначала неймовірну красу і силу його голосу, які, в повній мірі, компенсували деякі незначні огріхи його акторської майстерності $[9,478]$. Також тут потрібно згадати про “...виїмково великий успіх в опері “Жидівка" в ролі Єлеазара у Львівській опері...” [2, 327], який супроводжував виступи артиста 1927 року. "Молитва" зі згаданої опери Ф. Галеві у виконанні М. Голинського, особливо припала до душі вибагливій львівській публіці. 


\section{МИХАЙЛО ГОЛИНСЬКИЙ-СПІВАК СВІТОВОЇ СЛАВИ}

Згодом співак отримує запрошення до Поморської опери (об’єднання театрів міст Торунь, Бидгощ, Грудзьонз), де співає провідні партії в операх "Галька" С. Монюшка, "Кармен” Ж. Бізе, “Тоска” Дж. Пуччіні, “Аїда” Дж. Верді. Його висока виконавська майстерність допомогла здобути визнання польської публіки та прихильність критиків. 1925 року М. Голинський одружується з Галиною Красноперою (1902 1976), яка отримавши добру музичну освіту у Львівських професорів Д. Старосольської і В. Барвінського (фортепіано), Ч. Заремби і Р. Любінецького (сольний спів), С. Людкевича (теорія музики), стала незмінним концертмейстером та порадником для співака. У 20 - 30-х роках подружжя неодноразово виступали разом у концертах в Галичині та Наддніпрянщині $[3,85]$.

Навесні 1926 року митець уклав контракт 3 Великим Варшавським театром, а вже восени, він став солістом Одеської опери. Як зазначає М. Жишкович - “Саме М. Голинському першому 3-поміж галицьких співаків першої третини XX століття випала велика честь долучитися до утворення і становлення Державних оперних театрів в Одесі, Києві та Харкові. 31926 р. по 1930 р. співак був окрасою в царині українського оперного мистецтва” $[4,70]$. Впродовж 1927 - 1930 років М. Голинський соліст Київської та Харківської опер. Його партнерами по сцені були уславлені виконавці, серед яких Марія Литвиненко-Вольгемут, Марія Сокіл, Іван Паторжинський, Марія Донець. Потрібно відзначити, що 3 ініціативи М. Голинського 1929 року в Харкові була вперше поставлена опера Анатоля Вахнянина "Купало", в якій співак виконував роль Степана. Творчий період, який М. Голинський провів у Харкові можна вважати найбільш продуктивним, адже на сцені Харківської опери співак виконав партії: Радамеса (“Аїда" Дж. Верді), Хозе (“Кармен” Ж. Бізе), Каніо ("Паяци” Р. Леонкавалло), Германа ("Пікова дама" П. Чайковського), Гофмана (“Казки Гофмана” Ж. Оффенбаха), Каварадоссі та Калафа (“Тоска" і “Турандот” Дж. Пуччіні), Степана (“Купало” А. Вахнянина). Як один 3 найбільш репрезентативних солістів Харківської опери, 1029 року він брав участь у Днях української культури в Москві. Після успішного виступу М. Голинський отримав запрошення Великого театру на гостинні виступи. Примітним $\epsilon$ той факт, що в Москві, знаний виконавець, вперше за всю театральну історію, співав в опері Дж. Верді “Аїда” партію Радамеса українською мовою. "В Московський Великий театр запросили на два гастрольні виступи прем'єра Харківської опери драматичного тенора Михайла Голинського. На долю артиста випала роль вперше на сцені Великого театру в Москві співати українською мовою, бо в історії цього театру ні за царських часів, ані в післяреволюційній добі таких випадків не було... Значний художній успіх свідчить про те, що артист прекрасно справився 3 своїм завданням. 3 самого початку М. Голинський заволодів увагою слухачів. Емоційний підйом, рельєфний образ, вокальні дані і вміння володіти своїм голосом, який часто перекривав оркестр, забезпечили артистові надзвичайний успіх i висунули його в перші ряди кращих сучасних артистів вокалістів" [6, 16-17]-писала тогочасна харківська преса. Згодом - 1930 року, рідною мовою він також виконував партію Каварадоссі в опері Дж. Пуччіні “Тоска” на сцені оперного театру у Тбілісі.

Після повернення в Галичину М. Голинський бере активну участь у музичному та громадському житті краю. Навколо нього консолідуються прогресивні діячі культурного громадянства. Митець багато концертує, вшановуючи своїми виступами видатних подвижників української культури, літератури, мистецтва, а саме: Т. Шевченка, І. Франка, Б. Лепкого, М. Лисенка та інших митців. Впродовж $1930-$ 1938 років співак також продовжує виступати на сценах оперних театрів Львова, Варшави, Познані.

1938 року на запрошення української діаспори митець розпочав своє концертне турне США і Канадою. "Великим успіхом в Америці й Канаді, і скрізь, де тільки виступав, користувався Михайло Голинський... Якість його голосу є й досі між українськими співаками неперевершена" [6, 24] - зауважив А. Рудницький. Початок Другої світової війни та окупація Галичини радянською владою спричинилися до того, що митець залишився на американському континенти до кінця свого життя. Цей період став вагомою сторінкою його творчо-виконавської кар'єри, яку він спрямував на популяризацію української камерно-вокальної музики. Показовим в цьому контексті став перший концерт митця, який відбувся 26 листопада 1938 року в НьюЙоркському концертному залі “Тown Holl”. Окрім оперних арій, в його програму увійшли твори М. Лисенка, О. Нижанківського, Н. Нижанківського, С. Людкевича, М. Гайворонського, В. Балтаровича, Д. Січинського, М. Гайворонського. Описуючи виконавську майстерність та художню постать співака мистецтвознавець П. Маценко в НьюЙоркській газеті “Націоналіст” від 15 лютого 1939 року зауважив: “Голос М. Голинського міцносильний, одночасно милий, ніжний, рівний у 
всьому діапазоні, чи, точніше, вирівняний i вишліфуваний до досконалості... Володіє артист голосом вільно. Слухач ніколи не відчує напруження... Одначе артист уміє надати голосові відтінків звучання: блиску й дзвінкості, міді і срібла, а потім раптово примусити слухачів пережити враження дотику до оксамиту, шовку... Дикція доведена артистом до вершини мистецтва... Голинський-великий інтерпретатор... Манера і способи виконання, помножені на притаманну українському співу сердечність і глибину почуттів, обумовлюють його стиль “бельканто” (красивий спів)...” [6, 25 - 26].

Мистецька діяльність співака була гідно поцінована в Канаді. “Його називають “українським Карузо”, схвальні рецензії його тріумфальних виступів у Канаді надруковані у англомовній пресі" [5,366] - читаємо в дослідженні Г. Карась Він був обраний почесним громадянином Оттави і Вінніпегу та удостоєний Золотого Ключа від міста Торонто. Навіть під час урочистої церемонії вручення Ключа М. Голинський залишився, насамперед, патріотом своєї держави. “Я дуже вдячний за честь, яку Ви мені віддали, бо коли так віддаєте мені честь, то віддаєте іiі також моєму українському народові” $[3,116]$ - сказав митець.

Проживаючи від 1945 року в Торонто М. Голинський не лише займався концертновиконавською діяльністю, а й багато часу приділяв громадському життю української діаспори. Він часто відвідував осередки, де проживали українці, був активним дописувачем в українській пресі. Тривалий час очолював культурно-мистецьке об'єднання “Козуб”, яке було засновано 1956 року у Торонто з метою збереження, піднесення й пропагування української, канадської та інших культур. 3 кінця 1960-х років до 1973 - митець головував в згаданому об'єднанні та був активним організатором виступів багатьох митців 3 музичної та літературної сфер, ініціатором творчих дискусій, оглядачем актуальних новин культурномистецького життя. Також він долучався до проведення творчих конкурсів, участь в яких спонукала виступаючих до підвищення фахового рівня та творчих пошуків. Потрібно відзначити, що М. Голинський, чий голос став окрасою багатьох українських та світових сцен, завжди пишався тим, що був українцем. Як сам зауважував - “...сміливо обстоював і всюди, де лише міг, підкреслював, що я українець. ...я всюди підкреслював моє “українство” і за нього (де було потрібно) все палко дискутував, обстоював і навіть сварився" [2, 208 - 209]. Тут варто наголосити, що до 1993 року, коли світ побачило перше видання “Спогадів” [1] митця, він, на жаль, на батьківщині був менше відомий, ніж у світі. Ця книга відіграла свою унікальну роль, представивши українським шанувальникам вокального мистецтва пострадянської доби особистість визначного співака та громадянина.

Повертаючись до заокеанського періоду, зауважимо, що 1967 року М. Голинський оселився в Едмонтоні. 3 цього часу митець розпочав написання згаданих “Спогадів", в яких залишив своїм послідовникам відомості про найдрібніші деталі свого насиченого цікавими подіями та мистецькими злетами життя. Окрім цього, в книзі можна віднайти поради видатного співака 3 величезним виконавським та сценічним досвідом, які він давав співакам-початківцям. Зокрема митець говорив: “Я щиро раджу кожному молодому співакові, який мріє стати професійним оперним артистом, звертати велику увагу на вибір доброго професора-співака який сам зробив кар'єру, мав великий досвід на великих сценах, а також добрих професорів співу. Вчитися треба 4-5 років... Попри навчання співу необхідно плекати і красу свого голосу (і всього організму), тобто не пити, не палити, загартовуватись, займатися гімнастикою, зберігати здорові зуби, які мають велике значення для співака. Це підтвердить кожний співак. ...найкраще брати уроки співу щоденно або через день. Гірше 2 рази на тиждень, а вже цілком недостатньо брати урок раз на тиждень. Це те саме, що людина їла раз на тиждень і мала бути з того сита і здорова" [1, 106 107]. Слушні зауваження співака, які він давав спираючись на власний багатий вокальновиконавський досвід, цілком актуальні й для сучасних педагогів та виконавців, адже стануть їм в нагоді та допоможуть досягнути вершин вокальної майстерності.

Висновок. Підсумовуючи, потрібно відзначити, що М. Голинський належить до тієї когорти митців, які становлять славу і гордість української та світової музичних культур. Отримавши визнання на провідних оперних та камерних сценах, він зробив значний внесок в розвиток вітчизняного та світового вокального виконавства. Проживаючи за кордоном, долучився до духовного збагачення представників української діаспори та міжнародної спільноти. Визначальною рисою життєвого та творчого шляху митця стала “українськість”, яка допомогла йому зберегти своє національне коріння і залишитися патріотом своєї держави навіть за кордоном.

\section{ЛІТЕРАТУРА}

1. Голинський М. Спогади. Переднє сл. та упоряд. С. Д. Козака. Київ, 1993. 368 с. 


\section{МИХАЙЛО ГОЛИНСЬКИЙ-СПІВАК СВІТОВОЇ СЛАВИ}

2. Голинський М. Спогади. Упор.: Г. Тихобаєва, I. Криворучка, Д. Білавич. Львів, 2006. 616 с.

3. Білавич Д. Внесок родини Голинських в утвердження української музичної культури в Канаді. Діаспора як чинник утвердження держави Україна у міжнародній спільноті. Українська діаспора у світовій цивілізації : тези доповідей II Міжнар. Наук.-практ. Конф., (Львів, 18-20 червня 2008 р.). Львів, 2008. С. 115-117.

4. Жишкович М. А. Михайло Голинський на сцені харківської опери (до питання творчих контактів). Наукові записки Тернопільського національного педагогічного університету імені Володимира Гнатюка. Серія: Мистецтвознавство. 2011. № 1. С. 70-74.

5. Карась Г. В. Музична культура української діаспори у світовому часопросторі XX століття: монографія. Івано-Франківськ, 2012. 1164 с.

6. Козак С. Героӥчний тенор Михайло Голинський. Голинський М. Спогади. Упор.: Г. Тихобаєва, І. Криворучка, Д. Білавич. Львів, 2006. C. $12-36$.

7. Мазепа Л. Камерно-вокальні твори в класі сольного співу професора В. Висоцького. Наукові збірки Львівської національної музичної академії імені М.В.Лисенка “Камерно-вокальна творчість в історичній ретроспективі” : збірка статей. Серія: Виконавське мистецтво. Вип. 27. Львів: ТеРус, 2013. C. 101-113.

8. Михальчишин Я. 3 музикою крізь життя. Упор., вст. стаття Л. В. Мелех-Яросевич. Львів: Каменяр, 1992. 223 с.

9. Сабат-Свірська М. Михайло Голинський героїчний тенор. Українські співаки у спогадах сучасників. Автор-упор. І. Лисенко. Київ, 2003. C. $478-480$.

\section{REFERENCES}

1. Golynskyj, M. (1993). Spogady [Memoirs]. (Ed.). S. D. Kozak. Kyiv, 368 p. [in Ukrainian].

2. Golynskyj, M. (2006). Spogady [Memoirs]. (Eds.). G. Tykhobayeva, I. Kryvoruchka, D. Bilavich. Lviv, 616 p. [in Ukrainian].
3. Bilavych, D. (2008). Vnesok rodyny Golynskyx v utverdzhennya ukrayinskoyi muzychnoyi kultury v Kanadi [Contribution of the Golinsky family to the establishment of Ukrainian musical culture in Canada]. Diaspora as a factor in the establishment of Ukraine in the international community. Ukrainian Diaspora in the World Civilization: Abstracts II International. Science-Practice Conf. (Lviv, June 18-20, 2008). Lviv. pp. 115-117. [in Ukrainian].

4. Zhyshkovych, M. A. (2011). Myxajlo Golynskyj na sceni xarkivskoyi opery (do pytannya tvorchyx kontaktiv) [Michael Golinsky on the stage of the Kharkov opera (on the issue of creative contacts]. Scientific notes of Ternopil National Pedagogical University named after Volodymyr Hnatyuk. Series: Art Studies. No. 1.pp. 70-74. [in Ukrainian].

5. Karas, G. V. (2012). Muzychna kultura ukrayinskoyi diaspory u svitovomu chasoprostori XX stolittya: monografiya [Musical culture of the Ukrainian diaspora in the world time period of the twentieth century: a monograph]. Ivano-Frankovsk, 1164 p. [in Ukrainian].

6. Kozak, S. (2006). Geroyichnyj tenor Myxajlo Golynskyj [Heroic tenor Michael Golinsky]. Spogady. (Eds.). G. Tykhobayeva, I. Kryvoruchka, D. Bilavich. Lviv, pp. 12-36. [in Ukrainian].

7. Mazepa, L. (2013). Kamerno-vokalni tvory v klasi solnogo spivu profesora V. Vysoczkogo [Chamber-vocal compositions in the class of solo singing by Professor $\mathrm{V}$. Vysotsky]. Scientific collections of the $M V$ Lysenko Lviv National Music Academy "Chamber and Vocal Art in the Historical Retrospective": a collection of articles. Series: Performing Arts. Vol. 27. Lviv, pp. 101-113. [in Ukrainian].

8. Myhalchyshyn, Ya. (1992). Z muzykoyu kriz zhyttya [With music through life]. (Ed.). L.V. MelekhYarossevich. Lviv, 223 p. [in Ukrainian].

9. Sabat-Svirska, M. (2003). Myxajlo Golynskyj - geroyichnyj tenor [Michael Golinsky is a heroic tenor]. Ukrainian singers in the memoirs of contemporaries. (Ed.). I. Lysenko. Kyiv, pp. 478480. [in Ukrainian].

Стаття надійшла до редакції 21.06.2019

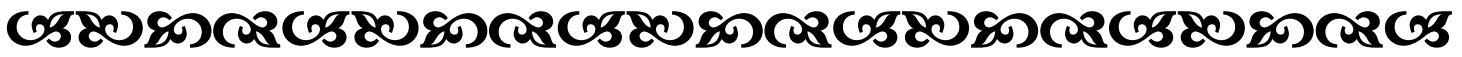

" $C$ свої радощі в кожному виді творчості: вся річ в тому, щоб вміти брати своє добро там, де його знаходять".

Оноре де Бальзак франиузький письменник

\section{ज58080}

